\title{
Evaluation of the Antioxidant Activity of Some Imines Containing $1 \mathrm{H}$-Benzimidazoles
}

\section{$1 \mathrm{H}$-Benzimidazol İçeren Bazı İminlerin Antioksidan Aktivitesinin Değerlendirilmesi}

\author{
(1) Rahman BAȘARAN*; (1) Gülgün KILCIGiL2², (1) Benay EKE3 \\ 1 University of Leeds, School of Chemistry, Leeds, United Kingdom \\ ${ }^{2}$ Ankara University Faculty of Pharmacy, Department of Pharmaceutical Chemistry, Ankara, Turkey \\ ${ }^{3}$ Ankara University Faculty of Pharmacy, Department of Pharmaceutical Toxicology, Ankara, Turkey
}

\begin{abstract}
Objectives: The in vitro antioxidant properties of some 2-(2-phenyl)-1H-benzo(d)imidazol-1-yl)- $\mathrm{N}^{\prime}$-(arylmethylene) acetohydrazide derivatives (1-12) were investigated in this study.

Materials and Methods: The in vitro antioxidant activity of compounds 1-12 was explored by determination of rat liver microsomal nicotinamideadenine dinucleotide phosphate dependent inhibition on lipid peroxidation (LPO) levels and microsomal ethoxyresorufin O-deethylase (EROD) activity.

Results: All synthesised compounds had LPO inhibitory activity (15-57\%) except compound 6, which contains a thiophene ring. Almost all the compounds displayed slightly inhibitory activity (2-20\%) on EROD.

Conclusion: The most active compound, 3 bearing a p-bromophenyl substituent at the second position of the benzimidazole ring, caused $57 \%$ inhibition of LPO level, while butylated hydroxytoluene showed $65 \%$ inhibition. None of the synthesised compounds had a marked inhibitory effect
\end{abstract} on EROD activity.

Key words: Antioxidant, benzimidazole, imine, lipid peroxidation, ethoxyresorufin O-deethylase activity

Öz

Amaç: Bu çalışmada, bazı 2-(2-fenil)-1H-benzo(d)imidazol-1-il)-N'-(arilmetilen) asetohidrazit türevlerinin in vitro antioksidan özellikleri araştırılmıştır. Gereç ve Yöntemler: 1-12 numaralı bileșiklerin in vitro antioksidan aktiviteleri, lipit peroksidasyon (LPO) düzeylerine sıçan karaciğer mikrozomal nikotinamid adenin dinükleotid fosfat bağımlı inhibisyonunu ve mikrozomal etoksirezorufin O-deetilaz (EROD) aktivitesinin belirlenmesiyle incelenmiștir.

Bulgular: Tiyofen halkası içeren bileșik 6 dışında, sentezlenen tüm bileșikler LPO inhibitör aktivite (\%15-57) göstermiștir. Hemen hemen tüm bileșikler az miktarda EROD inhibe edici aktivite (\%2-20) göstermiștir.

Sonuç: Benzimidazol halkasının ikinci konumunda p-bromo fenil sübstitüenti taşıyan bileşik 3, LPO seviyesinde \%57 inhibisyona neden olan en aktif bileșik iken, butillenmiş hidroksitoluen \%65 inhibisyon göstermiștir. Sentezlenen bileșiklerin hiçbiri EROD aktivitesi üzerinde belirgin bir inhibisyon etkisine sahip değildir.

Anahtar kelimeler: Antioksidan, benzimidazol, imin, lipit peroksidasyon, etoksirezorufin O-deetilaz

*Correspondence: E-mail: cmrb@leeds.ac.uk, Phone: 00447902047533 ORCID-ID: orcid.org/0000-0001-9640-2730

Received: 30.09.2019, Accepted: 31.10.2019

๑Turk J Pharm Sci, Published by Galenos Publishing House. 


\section{INTRODUCTION}

Antioxidant-defence mechanisms are present in living cells to maintain cellular homeostasis and survival by preventing cellular damage caused by oxidative stress in various diseases., ${ }^{1,2}$ Impairment of antioxidant mechanisms causes the balance between antioxidant defences and oxygen-derived free radicals to shift in favour of free radicals, resulting in oxidative stress. Therefore, the synthesis of novel drugs with antioxidants and free radical scavenging properties can help to treat and/or prevent diseases induced by insufficient antioxidant capacity. It is well recognised that lipid peroxidation (LPO) is a freeradical-mediated chain process that results in oxidative damage to cell membranes and other lipid-containing structures. ${ }^{3}$ It is an important tool to probe the antioxidant capacity of a novel compound. Almost all LPO products have long been reported to possess carcinogenic and/or mutagenic effects. Moreover, reactive oxygen species are generated by a variety of cellular mechanisms including cytochrome P450 (CYP450) enzymes, which catalyse a wide range of endogenous and exogenous substances, and particularly CYP1A1/2 have great importance in nicotinamide-adenine dinucleotide phosphate (NADPH)dependent LPO. Probing the effects of synthesised compounds on LPO levels and the CYP450 system is, therefore, crucial. ${ }^{4}$

Benzimidazoles have become an attractive pharmacophore in drug design and discovery, and exhibit a wide range of biological activities, e.g., antimicrobial, ${ }^{5-7}$ antiparasitic, ${ }^{8}$ antihistaminic, ${ }^{9}$ anticancer, ${ }^{10-15}$ antiallergic, ${ }^{16}$ and antioxidant. ${ }^{17-26}$ The synthesis, characterisation, and antioxidant capacities of some benzimidazole derivates containing thiadiazole, triazole, oxadiazole, and thiazolidinone rings at the first position have been reported in previous studies, ,618-21,23-25 and most of these compounds have been shown to possess substantial antioxidant properties. In the present study, the antioxidant properties of some benzimidazole derivatives having aryl-methylene amino acetamide (1-12) (Table 1), which have previously shown epidermal growth factor receptor kinase inhibitory activity, were investigated. ${ }^{13}$

\section{MATERIALS AND METHODS}

\section{General synthetic method}

All the desired benzimidazole-derived compounds were synthesised as described in Scheme 1 below. 2-phenyl-1Hbenzo(d)imidazole (I) was produced via oxidative condensation of o-phenylenediamine, benzaldehyde, and sodium metabisulphite. Treatment of / with ethyl chloroacetate in $\mathrm{KOH} /$ dimethyl sulphoxide (DMSO) yielded the $\mathrm{N}$-alkylated product ethyl 2-(2-phenyl)-1H-benzo[d]imidazol-1-yl) acetate (II). Hydrazine hydrate and the ester (II) in ethanol were refluxed for $4 \mathrm{~h}$ to obtain the desired hydrazide compound, 2-(2-phenyl)$1 \mathrm{H}$-benzo(d) imidazol-1-yl) acetohydrazide (III). Compounds 1-12 were achieved by condensing acyl hydrazide III with the corresponding aromatic aldehyde derivatives in the presence of sulphuric acid. ${ }^{13}$

\section{Treatment of animals}

Male albino Wistar rats weighing 200-225 g were used throughout the experiments. All animals were housed in single cages under controlled laboratory conditions $\left(22-25^{\circ} \mathrm{C}\right.$ room temperature; 12-h light/dark cycle; optimum humidity) and had access to standard rat chow and tap water ad libitum. They were deprived of feed for 24-h before sacrifice and then decapitated under anaesthesia. Their liver tissues were carefully dissected and immediately stored in a freezer at $-80^{\circ} \mathrm{C}$. All procedures used in the present study were approved by the Ethics Committee for Animal Experiments of Ankara University (2015-8-117).

\section{Isolation of rat liver microsomes}

The rat liver tissues were weighed and homogenised with $1.15 \%$ $\mathrm{KCl}(\mathrm{w} / \mathrm{v})$ at $3000 \mathrm{rpm}$ on ice and centrifuged at $11000 \mathrm{xg}$ for $25 \mathrm{~min}$. Once the supernatant fractions had been centrifuged again at $108000 \times \mathrm{g}$ for $60 \mathrm{~min}$, the pellets were mixed with $20 \%$ glycerol and were then immediately stored at $-80^{\circ} \mathrm{C}$ until use. Total protein levels of the liver microsomes were measured as described by Lowry et al. ${ }^{27}$ using bovine serum albumin as a standard.

\section{In vitro antioxidant activity}

\section{Lipid peroxidation assay}

The NADPH-dependent LPO level was determined based on the optimum conditions described previously. ${ }^{28}$ In this protocol, the control activity was determined as the pure diluent in which the chemicals were dissolved. DMSO was used as a control for the synthesised compounds. The assay was, therefore, performed only in a solvent as a control or the determined concentrations of compounds. The protocol was carried out as described by Wills ${ }^{29,30}$ with some modifications by Bishayee and Balasubramanian. ${ }^{31}$ The measurement of thiobarbituric acid reactive substances (TBARS) is the well-established method for quantifying NADPH-dependent LPO levels. This method is based on the principle of spectrophotometrically measuring the coloured product formed by the reaction of TBA with malondialdehyde (MDA) at $532 \mathrm{~nm}$. The amount of TBARS was then indicated as nanomoles of MDA/mg protein; $1 \mathrm{~mL}$ of reaction mixture contains $0.2 \mathrm{mg}$ of microsomal protein, 62.5 $\mathrm{mM}$ potassium phosphate buffer ( $\mathrm{pH} 7.4$ ), $0.2 \mathrm{mM} \mathrm{Fe} \mathrm{F}^{2+}, 90 \mathrm{mM}$ $\mathrm{KCl}$, and cofactor (NADPH-generating system) consisting of 2.5 $\mathrm{mM}$ glucose-6-phosphate, $14.2 \mathrm{mM}$ potassium phosphate buffer ( $\mathrm{pH}$ 7.8), $2.5 \mathrm{mM} \mathrm{MgCl}_{2}, 0.25 \mathrm{mM} \mathrm{NADP}^{+}$, and $1.0 \mathrm{U}$ of glucose6-phosphate dehydrogenase. The reaction was initiated by the addition of an NADPH-generating system and then allowed to incubate at $37^{\circ} \mathrm{C}$ for $30 \mathrm{~min}$ in a shaking water bath. At the end of the incubation, the reaction was terminated by the addition of $500 \mu \mathrm{L}$ of $25 \%$ trichloroacetic acid and then centrifuged at 5 $000 \mathrm{rpm}$ for $20 \mathrm{~min}$ to remove denatured proteins. Next, $1 \mathrm{~mL}$ supernatant was combined with $0.5 \mathrm{~mL}$ of TBA and the mixture was then boiled for $20 \mathrm{~min}$ in a hot water bath. Finally, the absorbance was read spectrophotometrically at a wavelength of $532 \mathrm{~nm}$. Whilst butylated hydroxytoluene (BHT) was used as a standard, the control used in this assay was DMSO.

\section{7-Ethoxyresorufin O-deethylase (EROD) assay}

EROD activity in the rat liver microsomes was assayed as previously described by Burke et al. ${ }^{32}$ 7-ethoxyresorufin is a substrate for CYP1A1, and this enzyme converts it to resorufin, 
Table 1. In vitro effects of compounds 1-12 on liver LPO levels and EROD enzyme activities. Concentration in incubation medium (10-3 M). All the values are means \pm SD of three independent experiments

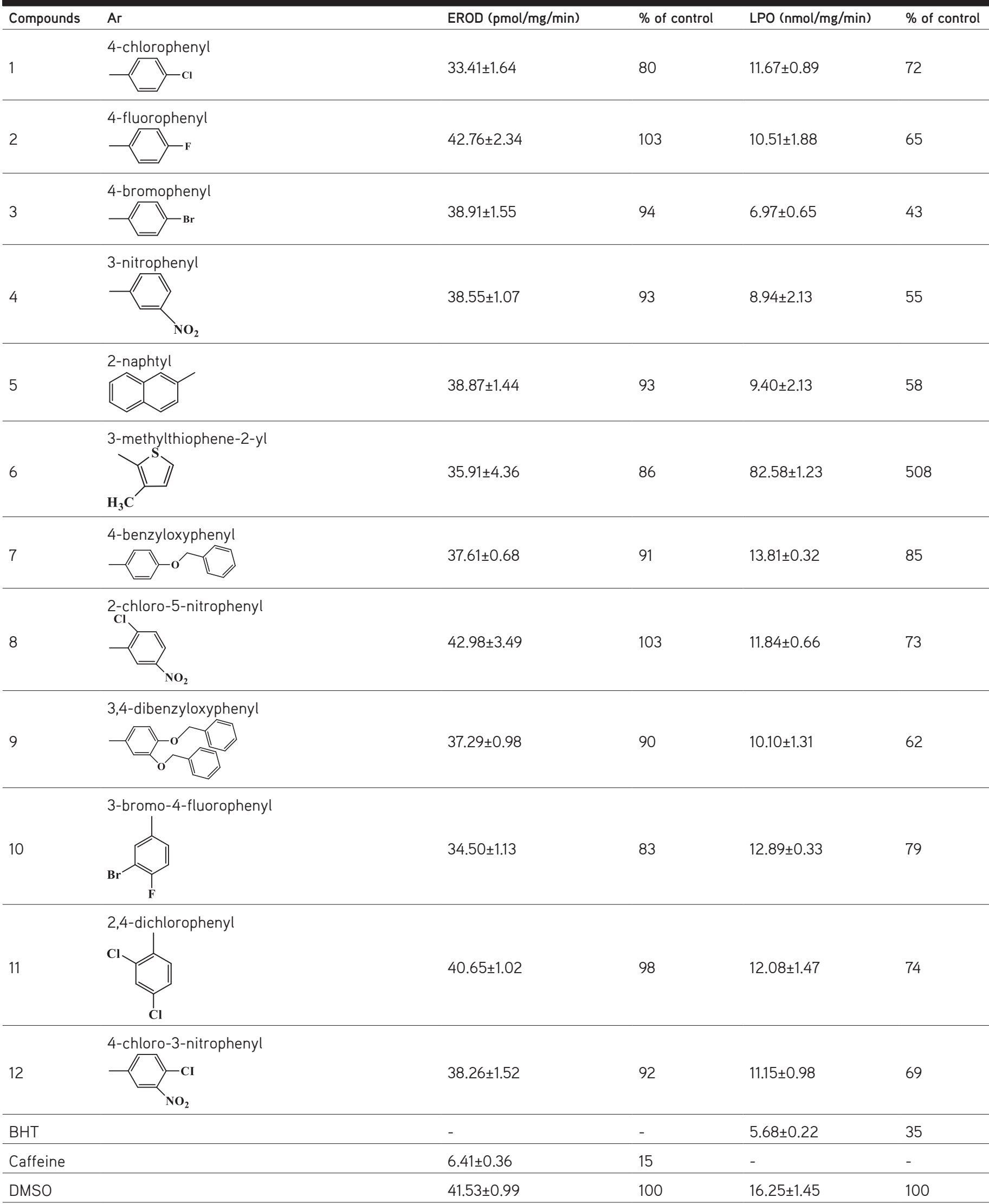

LPO: Lipid peroxidation, EROD: 7-ethoxyresorufin O-deethylase, SD: Standard deviation, BHT: Butylated hydroxytoluene, DMSO: Dimethyl sulphoxide 


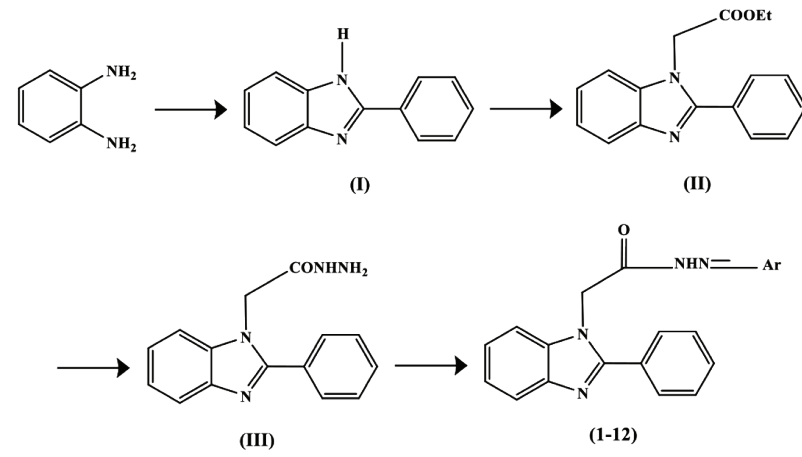

Scheme 1. Synthetic route to compounds 1-12

which can be measured spectrofluorimetrically. $1 \mathrm{~mL}$ of typical optimized reaction mixture contains $0.2 \mathrm{mg}$ of rat liver microsomal protein, $1.0 \mathrm{mM} 7$-ethoxyresorufin as a substrate, $100 \mathrm{mM}$ Tris- $\mathrm{HCl}$ buffer (pH 7.8), $12 \mathrm{mM}$ albumin, $10^{-3} \mathrm{M}$ test compound, and an NADPH-generating system consisting of 2.5 $\mathrm{mM}$ glucose-6-phosphate, $14.2 \mathrm{mM}$ potassium phosphate buffer (pH 7.8), $2.5 \mathrm{mM} \mathrm{MgCl}_{2}, 0.25 \mathrm{mM} \mathrm{NADP}$, and $1.0 \mathrm{U}$ of glucose6-phosphate dehydrogenase. The reaction was initiated by the addition of the NADPH-generating system and then allowed to incubate at $37^{\circ} \mathrm{C}$ for $5 \mathrm{~min}$. After incubation, the reaction was stopped by the addition of $3 \mathrm{~mL}$ of ice-cold methanol and then centrifuged at $5000 \mathrm{rpm}$ for $20 \mathrm{~min}$ to remove the denatured proteins. Finally, the absorbance was measured spectrofluorimetrically at the excitation wavelength of $538 \mathrm{~nm}$ and the emission wavelength of $587 \mathrm{~nm}$. Whilst caffeine was used as a standard, the control used in this assay was DMSO.

\section{RESULTS}

The antioxidant effects of synthesised compounds on the rat liver microsomal NADPH-dependent LPO levels were ascertained by quantifying the amount of 2-TBARS formed in the reaction (Table 1). The results indicated that all synthesised compounds at a concentration of $10^{-3} \mathrm{M}$ had LPO inhibitory activity except compound 6 , which contains thiophene, that well-known isoster of the phenyl ring as an aryl group, and the rates were in the range of $15-57 \%$. Compounds 2, 4, 5, 9, and 12 have moderate inhibitory activity on LPO levels in the range of $31-45 \%$. The most active compound, 3 , bearing a $p$-bromophenyl substituent at the second position of the benzimidazole ring, caused $57 \%$ inhibition of LPO level, while BHT displayed 65\% inhibition at the same concentration.

The in vitro effects of compounds on rat liver microsomal EROD activity were also tested. The results showed that none of the synthesised compounds had a marked inhibitory effect on EROD activity. Almost all the compounds displayed slightly inhibitory activities (2-20\%) on EROD when the value of caffeine was 85\% (Table 1).

\section{DISCUSSION AND CONCLUSION}

In our previous studies, we described the synthesis and antioxidant effects of 2-[2-(4-chlorophenyl)benzimidazole-1yl]-N-(2-arylmethylene amino)] acetamides on EROD activity and LPO levels. ${ }^{21,33}$ When compared with the results obtained from these studies, benzimidazoles carrying a 4-chloro phenyl ring at the second position were found to be more effective than the benzimidazole counterpart carrying nonsubstituted phenyl rings for both assays.

Conflicts of interest: No conflict of interest was declared by the authors. The authors alone are responsible for the content and writing of the paper.

\section{REFERENCES}

1. Grune T. Oxidants and antioxidant defence systems. The Handbook of Environmental Chemistry Vol. 2: Reactions, Processes; Springer, Berlin, 2005.

2. Huang D, Ou B, Prior RL. The chemistry behind antioxidant capacity assays. J Agric Food Chem. 2005;53:1841-1856.

3. Halliwell B, Chirico S. Lipid peroxidation: its mechanism, measurement, and significance. Am J Clin Nutr. 1993;57:715S-25S.

4. Cadenas E, Packer L. Handbook of Antioxidants. $2^{\text {nd }}$ ed. Revised and Expanded; Marcel Dekker: New York-Basel, 2002.

5. Ayhan-Kilcigil G, Tuncbilek M, Altanlar N, Goker H. Synthesis and antimicrobial activity of some new benzimidazole carboxylates and carboxamides, II Farmaco. 1999;54:562-565.

6. Kus C, Sozudonmez F, Altanlar N. Synthesis and antimicrobial activity of some novel 2-[4-(substituted piperazin-/piperidin-1-ylcarbonyl) phenyl]-1H-benzimidazo-le derivatives. Arch Pharm Chem Life Sci. 2009;342:54-60.

7. Han-Bo L, Wei-Wei G, Vijai Kumar RT, Cheng-He Z, Rong-Xia G. Novel amino-pyrimidinyl benzimidazoles as potentially antimicrobial agents: Design, synthesis and biological evaluation. Eur J Med Chem. 2018;143:66-84.

8. Alp M, Goker H, Brun R, Yildiz S. Synthesis and antiparasitic and antifungal evaluation of 2'-Arylsubstituted-1H,1'H- [2,5']bisbenzimidazolyl-5carboxamidi-nes. Eur J Med Chem. 2009;44:2002-2008.

9. Goker H, Ayhan-Kilcigil G, Tuncbilek M, Kus C, Ertan R, Kendi E, Ozbey S, Fort M, Garcia C, Farré A. Synthesis and antihistaminic H1-Activity of 1,2,5(6)-Tri-substituted benzimidazoles. Heterocycles. 1999;51:25612573.

10. Al-Douh Mh, Sahib H, Osman H, Hamid S, Salhimi S. Anti-proliferation effects of benzimidazole derivatives on Hct-116 colon cancer and mcf-7 breast cancer cell Lines. Asian Pac J Cancer P. 2012;13:4075-4079.

11. Yadav S, Sinha D, Sing KS, Singh K. Novel benzimidazole analogs as Inhibitors of EGFR tyrosine kinase. Chem Biol Drug Des. 2012;80:625630 .

12. Hu Z, Ou L, Li S, Yang L. Synthesis and biological evaluation of 1-cyano2-amino-benzimidazole derivatives as a novel class of antitumor agents. Med Chem Res. 2014;23:3029-3038.

13. Demirel S, Ayhan Kilcigil G, Kara Z, Guven B, Onay Besikci A. Synthesis and pharmacologic evaluation of some benzimidazole acetohydrazide derivatives as EGFR inhibitors. Turk J Pharm Sci. 2017;14:285-289.

14. Jawaid AM, Anees AS, Ahsan AK, Zulphikar A. Design, synthesis, docking and QSAR study of substituted benzimidazole linked oxadiazole as cytotoxic agents. Eur J Med Chem. 2017;126:853-869. 
15. Cheong JF, Zaffagni M, Chung I, Xu Y, Wang Y, Jernigan FE, Zetter $B R$, Sun L. Synthesis and anticancer activity of novel water soluble benzimidazole carbamates. Eur J Med Chem. 2018;144:372-385.

16. Nakano H, Inoue T, Kawasaki N, Miyataka H, Matsumoto H, Taguchi T, Inagaki N, Nagai H, Satoh T. Synthesis and biological activities of novel antiallergic agents 5-lipoxygenase Inhibiting action. Bioorg Med Chem. 2000;8:373-380.

17. Can Eke B, Puskullu MO, Buyukbingol E, Iscan M. Study on the antioxidant capacities of some benzimidazoles in rat tissues. Chem Biol Interact. 1998;113:65-77.

18. Ayhan-Kilcigil G, Kus C, Coban T, Can-Eke B, Iscan M. Synthesis and anti-oxidant properties of novel benzimidazole Derivatives. J Enzym Inhib Med Chem. 2004;19:129-135.

19. Ayhan-Kilcigil G, Kus C, Coban T, Can-Eke B, Ozbey SM. Iscan. Synthesis, Antioxidant and Radical Scavenging Activities of Novel Benzimidazoles. J Enzym Inhib Med Chem. 2005;20:503-514.

20. Ayhan-Kilcigil G, Kus C, Ozdamar ED, Can-Eke B, Iscan M. Synthesis and antioxidant capacities of some new benzimidazole derivatives. Arch Pharm. 2007;340:607-611.

21. Ayhan-Kilcigil G, Gurkan S, Coban T, Ozdamar ED, Can-Eke B. Synthesis and evaluation of antioxidant properties of novel 2-[2-(4-chlorophenyl) benzimi-dazole-1-yl]-n-(2-arylmethylene amino) acetamides and 2-[2-(4-chlorophenyl) benzimidazole-1-yl]-n-(4-oxo-2-arylthiazolidine-3-yl) acetamides-I. Chem Bio Drug Des. 2012;79:869-877.

22. Ayhan-Kilcigil G, Kus C, Coban T, Can-Eke B, Ozdamar ED, Can-Eke B. Identification of a novel series of n-phenyl-5-[(2-phenylbenzimidazol-1yl)methyl]-1,3,4-oxadiazol-2-amines as potent antioxidants and radical scavengers. Arch Pharm. 2014;347:276-282.

23. Kus C, Ayhan-Kilcigil G, Can-Eke B, Iscan M. Synthesis and antioxidant properties of some novel benzimidazole derivatives on lipid peroxidation in the rat liver. Arch Pharm Res. 2004;27:156-163.
24. Kus C, Ayhan-Kilcigil G, Ozbey S, Kaynak FB, Kaya M, Coban T, CanEke B. Synthesis and antioxidant properties of novel n-methyl-1,3,4thiadiazol-2-amine and 4-methyl-2h-1,2,4-triazole-3(4h)-thione derivatives of benzimidazole class. Bio Med Chem. 2008;16:4294-4303.

25. Kerimov I, Ayhan-Kilcigil G, Can-Eke B, Altanlar N, Iscan M. Synthesis, antifungal and antioxidant screening of some novel benzimidazole derivatives. J Enzym Inhib Med Chem. 2007;22:696-701.

26. Kerimov I, Ayhan-Kilcigil G, Ozdamar ED, Can-Eke B, Coban T, Ozbey $\mathrm{S}$, Kazak C. Design and one-pot and microwave-assisted synthesis of 2-amino/5-aryl-1,3,4-oxadiazoles bearing a benzimidazole moiety as antioxidants. Arch Pharm. 2012;3457:549-556.

27. Lowry OH, Rosebrough NJ, Farr AL, Randall RJJ. Protein measurement with the Folin phenol reagent. Biol Chem. 1951;193:265-275.

28. Iscan M, Arinc E, Vural N, Iscan MY. In vivo effects of 3-methylcholantrene, phenobarbital, pyretrum and 2.4.5-T isooctylester on liver, lung and kidney microsomal mixed-function oxidase system of guinea-pig: a comparative study. Comp Biochem Physiol. 1984;77:77-190.

29. Wills ED. Mechanisms of lipid peroxide formation in animal tissues. Biochem J. 1966;99:667-676.

30. Wills ED. Lipid peroxide formation in microsomes. Relationship of hydroxylation to lipid peroxide formation. Biochem J. 1969;113:333-341.

31. Bishayee S, Balasubramanian AS. Lipid peroxide formation in rat brain. J Neurochem. 1971;18:909-920.

32. Burke MD, Thompson S, Elcombe CR, Halpert J, Haaparanta T, Mayer RT. Ethoxy-, pentoxy- and benzyloxyphenoxazones and homologues: a series of substrates to distinguish between different induced cytochromes P-450. Biochem Pharmacol. 1985;34:3337-3345.

33. Alp AS, Kilcigil GA, Ozdamar ED, Coban T, Eke B. Synthesis and evaluation of antioxidant activities of novel 1,3,4-oxadiazole and imine containing 1H-benzimidazoles. Turk J Chem. 2015;39:42-53. 